ORIGINAL RESEARCH PAPER

Presented at the $10^{\text {th }}$ International Symposium EuroAliment 2021

\title{
IMPACT OF SEA BUCKTHORN BERRIES (HIPPOPHAE RHAMNOIDES) ON YOGHURT BIOLOGICAL VALUE AND QUALITY
}

\author{
EUGENIA COVALIOV*, CAROLINA GROSU, VIOLINA POPOVICI, TATIANA CAPCANARI, \\ RODICA SIMINIUC, VLADISLAV RESITCA
}

\author{
Technical University of Moldova, 168 Stefan cel Mare blvd., MD 2004, Chisinau, Republic of \\ Moldova \\ *corresponding author: eugenia.boaghi@toap.utm.md
}

Received on 8 September 2021

Revised on 28 October 2021

\begin{abstract}
In this research, an integrated physico-chemical and sensory approach was implemented to study the impact of sea buckthorn addition in a fermented dairy product such as yoghurt. Yoghurt samples were prepared with the addition of sea buckthorn puree in different concentrations - 1\%,3\%,5\%,7\%. Thus, research was done to determine the impact of the addition of sea buckthorn on the quality of yoghurt. The obtained results demonstrate that fat content is decreasing from $4.43 \%$ for the sample with $1 \%$ sea buckthorn to $4.21 \%$ for the sample with $7 \%$ sea buckthorn, fact caused by the sea buckthorn addition, which replaces the milk quantity. The protein content for all samples meets the requirements of the regulation for dairy products ( $\min .1 .6 \%$ ), ranging from $3.29 \%$ to $2.6 \%$.

During fermentation and storage, the acidity values are increasing and this is most noticeable in samples with the highest sea buckthorn content due to the significant intake of acids from sea buckthorn that speed up the acidification. Following the organoleptic examination, it was deduced that the sample with 5\% and 7\% added sea buckthorn has favorable characteristics for the consumer, but the latter is to be improved because they have values of over $35 \%$ serum release.
\end{abstract}

Keywords: sea buckthorn, yoghurt, prebiotics, probiotics

\section{Introduction}

Milk and dairy products have long been recognized as an important component of a balanced diet. They provide a wide range of important nutrients, in addition, the evidence of the health benefits associated with the presence of specific components or bacteria is gradually gaining established scientific credibility (Visioli and Strata,

https://doi.org/10.35219/foodtechnology.2021.2.05 
2014). Therefore, it is understandable that among the best known examples of functional foods are fermented milk and yoghurts that contain probiotic bacteria (Bell et al., 2017).

Fruits and yoghurt have also been individually identified as indicators of healthy eating patterns (Fernandez and Marette, 2017).

Fruits have few calories, vitamins, minerals, and a high content of water and fiber, a combination that helps to achieve a feeling of satiety and helps to control weight (Dreher, 2018). On the other hand, yoghurt is a food that incorporates almost all the substances that the human body needs to function properly: calcium, phosphorus, magnesium, potassium, B-complex vitamins, proteins, probiotics, all of which play an important role in protecting the immune system (Laird et al., 2017). Yoghurt and fruit contain many nutrients that have the ability to act in a complementary and synergistic way on health (Yanni et al., 2020). The benefit of consuming fruit yoghurt is the potential of fruit prebiotics to support the effect of probiotics in yoghurt, as well as to provide an environment conducive to their action as soon as they reach the colon (Yanni et al., 2019). Currently, on the global market, there is already a diverse range of fruit yoghurt (raspberries, strawberries, peaches, etc.), but research does not stop here, so new ideas are being implemented to enrich products with natural supplements.

Sea buckthorn (Hippophae rhamnoides L.) fruits have a generally sour taste, similar to that of apple and pineapple. Sea buckthorn berries are estimated to be the richest vitamin $\mathrm{C}$ fruit ever discovered, although the exact content varies from variety to variety, this fruit contains on average more than $600 \mathrm{mg}$ of vitamin $\mathrm{C}$ per 100 g, 30 times more than orange (Kuhkheil et al., 2017). Sea buckthorn berries also contain other powerful antioxidants from the polyphenol family, including carotenoids, which are responsible for the color orange and flavonoids (Shi et al., 2019). Due to the huge arsenal of biologically active compounds (Roman et al., 2020), sea buckthorn fruits are added to many food matrices such as cream cheese (Ghendov-Moşanu et al., 2020), muffins (Ursache et al., 2018), emulsions (Zheng et al., 2020), bread (Guo et al., 2019), etc. The incorporation of sea buckthorn in yoghurt is not widespread. Attempts to incorporate sea buckthorn powder into yoghurt have been made by Sidor et al. (2017), however, in the process of obtaining the powder, some biologically active compounds, such as vitamin $\mathrm{C}$, can be destroyed (Verbeyst et al., 2013).

Considering this fact, the enrichment of yoghurt with this local fruit very little valorized is a current topic.

Thus, the actuality of the subject derives on the one hand from the fact that numerous researches reported that yoghurt and fruits consumed together could help control weight and reduce the risk of disease, and on the other hand, that sea buckthorn fruits have a high content of polyphenols, vitamins, minerals, etc., but are poor valorized. In this sense, the research of the impact of sea buckthorn addition on the quality of yoghurt is current. 


\section{Materials and methods}

Sea buckthorn (Hippophae rhamnoides L.) cultivated in the Republic of Moldova was used in the study and was added to the yoghurt composition in the form of puree, in order to keep the bioactive components in a viable form. Fruits were rinsed well under cold water and in a blender were crushed for about 1 minute until the puree phase. The obtained mass was gradually poured into a sieve and was gradually pressed to eliminate the juice.

The freeze dried Sacco YAB 352 B LYO starter culture (containing a mixture of Streptococcus thermophilus, Lactobacillus delbrückii subspecies Bulgaricus, Bifidobacterium lactis) was purchased from Innolact Finland.

\section{Yoghurt manufacture}

The yoghurt was prepared in laboratory conditions from cow's milk, with a fat content of $3.5 \%$. The yoghurt samples were prepared as described by Chandan (2006), using as raw materials cow milk $(91 \%)$, whole milk powder $(3 \%)$, sugar $(3 \%)$, and starter culture (3\%). The starter culture dose (3\%) was used according to producer recommendation. Initially, the milk was pasteurized at a temperature of $90-95^{\circ} \mathrm{C}$ for 3 to 5 minutes, the treatment aiming at the destruction of pathogenic and unwanted bacteria present in vegetative form, which will favor the further development of ferments and promote the development of specific lactic cultures. The pasteurized milk was cooled to a temperature of $42^{\circ} \mathrm{C}$ and then inoculated with lactic acid bacteria. Further yoghurt samples were prepared by partially replacing the milk and sea buckthorn puree was introduced in a ratio of 1,3,5, and $7 \%$ of the total weight.

\section{Dry matter content determination}

Dry matter was determined using the Axis BTS 110 Thermal Balance, whose operating principle is to dry the sample on an aluminum support, in order to automatically determine the humidity of the sample. The mode percentage of the dry mass of the initial mass was used for the experiment. The samples were dried at a temperature of $110^{\circ} \mathrm{C}$ until a constant mass of dry residue was obtained.

\section{Fat content determination}

Fat content was determined by the standard acid-butyrometric method according to Kleyn et al. (2001). In the milk butyrometer are added $10 \mathrm{~mL}$ of sulfuric acid $(\rho=$ $\left.1,810-1,812 \mathrm{~g} / \mathrm{cm}^{3}\right), 5 \mathrm{~mL}$ of yoghurt, and $6 \mathrm{~mL}$ of distilled water. Then $1 \mathrm{~mL}$ of isoamyl alcohol is added ( $\rho=0.810-0.812)$. The butyrometer is wiped, the rubber stopper is screwed on, and the mixture is homogenized. After homogenization, the butyrometer is centrifuged for 5 minutes at 1000-1200 rpm, removed from the centrifuge and placed on the water bath at a temperature of $65^{\circ} \mathrm{C}$. The percentage of fat is read on the butyrometer scale (Kleyn et al., 2001).

\section{Protein content determination}

Protein content was determined by the formaldehyde titration method (Pyne, 1932). A sample of yoghurt is titrated to the phenolphthalein endpoint ( $\mathrm{pH} 8.4$ ) with $0.1 \mathrm{M}$ $\mathrm{NaOH}$, formaldehyde is then added; the red color fades and the sample is re-titrated 
with $\mathrm{NaOH}$ - the volume of $\mathrm{NaOH}$ required for the second titration is proportional to the concentration of lysine, and hence protein, in the sample.

\section{Titratable acidity and $\mathrm{pH}$ determination}

Titratable acidity was determined by the titrimetric method and expressed in $\%$ the principle of which is to neutralize the acidic substances in yoghurt with $0.1 \mathrm{n} \mathrm{NaOH}$ solution using phenolphthalein as an indicator (Sadler and Murphy, 2010).

Changes in the $\mathrm{pH}$ of yoghurt samples during fermentation and storage were determined using a digital $\mathrm{pH}$-meter. The $\mathrm{pH}$ value was obtained by simply reading the $\mathrm{pH}$ meter screen.

\section{Viscosity determination}

Viscosity was determined using the Brookfield DV-IIITM Ultra Rheometer which measures the viscosity of the fluid while rotating the spinner immersed in the tested sample.

\section{Syneresis index determination}

The stability of the yoghurt samples was determined by measuring the amount of whey spontaneously separated from milk gels fermented in volumetric flasks. The principle of the method consists of the separation between the solid (gel) and liquid phase during the coagulation of milk as a result of active physico-chemical phenomena (restructuring of the casein network) and passive ones (porosity and permeability of the gel). The syneresis was expressed as the percentage of separated whey over the initial weight of the yoghurt sample.

\section{Lactic bacteria growth}

Optical density (OD) measurement of microbial growth is one of the most common techniques used in microbiology, with applications from growth studies in different nutrient or stress environments to antibiotic efficacy studies and characterization of different mutant strains (Li and Mira de Orduña, 2010; Stevenson et al., 2016). In order to monitor the development of bacterial cells in the fermentation medium, a colorimetric determination was performed on a Heidolf spectrophotometer $(600$ $\mathrm{nm}$ ), after prior dilution with distilled water. For this purpose, $1 \mathrm{ml}$ of the homogeneous fermentation medium is diluted with $9 \mathrm{ml}$ of distilled water, stirred, and the extinction is read on a spectrophotometer against distilled water. The optical density is calculated according to the following formula:

$$
\text { O.D. }=\mathrm{E}_{600} \cdot 10
$$

where: $\mathrm{E}_{600}$ - extinction at $600 \mathrm{~nm} ; 10$ - sample dilution.

Spectrophotometric measurements at $660 \mathrm{~nm}$ were performed periodically in triplicate in order to establish growth parameters. Results were statistically processed. 


\section{Sensorial analysis}

In order to perform the sensorial test, yoghurt samples were prepared one day in advance. Fifteen panelists (aged 22 to 50 years old), participated in this study and appreciated the quality of yoghurts based on the 5-point hedonic scale from "dislike extremely" to "like extremely". Visual appearance consisting of an examination of the surface of the yoghurt (presence of whey), texture, and taste (whey taste, sour, salty, sweet, astringent, and after-taste) were appreciated.

\section{Statistical analysis}

All experiments were performed in triplicates. The results are given as mean \pm standard deviation (SD). The data were statistically analyzed by ANOVA and Tukey tests $(\alpha=0.05)$.

\section{Results and discussion}

\section{Impact of sea buckthorn addition on the chemical composition of yoghurt}

The dry matter is all the solid components of milk, namely fats, proteins, carbohydrates and minerals (Jeantet et al., 2008). A low total solids content can cause syneresis which is defined by a separation between the serum and the solid structure, causing the accumulation of liquids on the yoghurt surface. It is possible to increase the percentage of total solids in the yoghurt mixture by adding whole or partially skimmed milk powder, casein powder, a whey protein concentrate, or hydrolyzed proteins (Hachana et al., 2017). In the present research, whole milk powder was used. Sea buckthorn puree was added to the yoghurt composition by substituting milk. The evolution of the macronutrient composition of yoghurt depending on the amount of added sea buckthorn puree (SBP) is presented in table 1 .

Table 1. Impact of sea buckthorn puree addition on the macronutrient content of yoghurt samples.

\begin{tabular}{lccc}
\hline & Dry matter, \% & Fat, \% & Proteins, \% \\
\hline Control sample & $20.80 \pm 0.22^{\mathrm{ab}}$ & $4.50 \pm 0.12^{\mathrm{a}}$ & $3.10 \pm 0.07^{\mathrm{a}}$ \\
SBP 1 \% & $20.10 \pm 0.34^{\mathrm{b}}$ & $4.43 \pm 0.14^{\mathrm{a}}$ & $3.29 \pm 0.10^{\mathrm{a}}$ \\
SBP 3 \% & $20.43 \pm 0.19^{\mathrm{b}}$ & $4.37 \pm 0.10^{\mathrm{a}}$ & $3.20 \pm 0.14^{\mathrm{a}}$ \\
SBP 5 \% & $20.62 \pm 0.24^{\mathrm{b}}$ & $4.29 \pm 0.12^{\mathrm{a}}$ & $2.72 \pm 0.09^{\mathrm{b}}$ \\
SBP 7 \% & $21.34 \pm 0.31^{\mathrm{a}}$ & $4.21 \pm 0.10^{\mathrm{a}}$ & $2.60 \pm 0.10^{\mathrm{b}}$
\end{tabular}

Insignificant differences ( $>0.05)$, a-e: in each column different letters mean significant differences $(\mathrm{p}<0.001)$.

The presented data shows that the addition of 1\%, 3\%, and 5\% SBP on sea buckthorn puree has the effect of reducing the dry matter content, thus registering a decrease from the initial content of $20.80 \%$ for the control sample to $20.62 \%$ for the test with 5\% added sea buckthorn, the results obtained are consistent with the results of other researchers (Soliman and Shehata, 2019). An antagonistic effect of the SBP addition is observed for the yoghurt sample $7 \%$ SBP for which the dry 
matter content constituted $21.34 \%$. However, deviations from the data for the control sample are not essential, this is probably due to the fact that the dry matter content of milk $(15.03 \%)$ is practically similar to that of sea buckthorn puree $(14.92 \%)$, the difference being in composition only. Thus, the substitution of milk in the recipe will cause the reduction of the protein intake of yoghurt, instead, the addition of sea buckthorn comes with an arsenal of biologically active substances such as vitamins, polyphenols, phytosterols, etc.

Fat is one of the important components of milk, and its content is variable depending on its composition. Milk fats are composed mainly of triglycerides, phospholipids, and an unsaponifiable fraction consists largely of cholesterol and $\beta$ carotene (Jeantet et al., 2008). The fat content naturally present in milk varies between 3.5\% and $4.5 \%$ depending on the breed of cows, their diet, and the season (Johnston and DeVries, 2018). The experimental obtained results show the presence of a high fat content, the control sample having a maximum fat content of $4.50 \%$. Subsequently, the fat content is decreasing, caused by the addition of SBP, which gradually replaces the milk weight of the product. Sea buckthorn fruits are known to be rich in essential lipids. However, sea buckthorn puree is deprived of a large amount of lipids due to the fact that they are concentrated in the skin and seeds of the fruit (Zielińska and Nowak, 2017). Depending on the used addition in the yoghurt recipe, many scientists have mentioned either increasing or decreasing the lipid content (Adhikari and Bajracharya, 2018). Yoghurts developed by Najgebauer-Lejko et al. (2021) with various fruits as additives showed lower lipid content $(1.28-1.63 \%)$.

Yoghurt is also known for its protein content, as it contains different types of casein $(\alpha, \kappa, \beta$ and $\gamma)$ and whey proteins, especially $\alpha$-lactalbumin, $\beta$-lactoglobulin, serum albumin, protease-peptones and immunoglobulins, metalloproteins such as lactoferrin, transferrin and ceruloplasmin and enzymes such as lipases, proteases, and phosphatases (Ebringer et al., 2008). In recent years, yoghurt peptides have been of great scientific interest. In particular, not only due to its antihypertensive, antimicrobial, immunomodulatory, and lipid-reducing properties but also has a significant effect on the prevention of abdominal obesity. According to the data presented in Table 1 for the protein content of yoghurt with SBP, it is observed that there is a variation in the level of protein from one sample to another caused by the sea buckthorn content. Thus, the protein content is indirectly proportional to the addition of SBP, registering values of $3.10 \%$ for the control sample and $2.60 \%$ for the sample with 7\% SBP. da Silva (2007) developed a symbiotic yoghurt that had a higher protein value $(5.01 \%)$, and Torres et al. (2000) studying commercial yoghurts reported the value of $4.29 \%$ protein. According to the Technical Regulation on the identity and quality of dairy drinks, they must contain at least $1.6 \%$ protein in their composition. The yoghurts developed in this paper meet this recommendation.

\section{The evolution of $\mathrm{pH}$ during fermentation}

Studies published in the works of various scientists claim that during the fermentation process, lactic acid produced by bacterial cultures causes a reduction 
in $\mathrm{pH}$, from an initial value of about 6.0 - 6.5 to a final $\mathrm{pH}$ of $4.0-4.6$ (Mediza Romero et al., 2021; Vénica et al., 2020). As soon as the pH of the product has reached the value within the limits of 4.0-4.6, the fermentation process is stopped by placing the yoghurt in the cold. $\mathrm{pH}$ deviations from the default value can shorten the shelf life or can result in a product with an undesirable consistency. Moreover, stopping fermentation too soon or too late can lead to intensified syneresis processes (Clark et al., 2009). Figure 1 presents the results on the evolution of yoghurt $\mathrm{pH}$ during the lactic fermentation process.

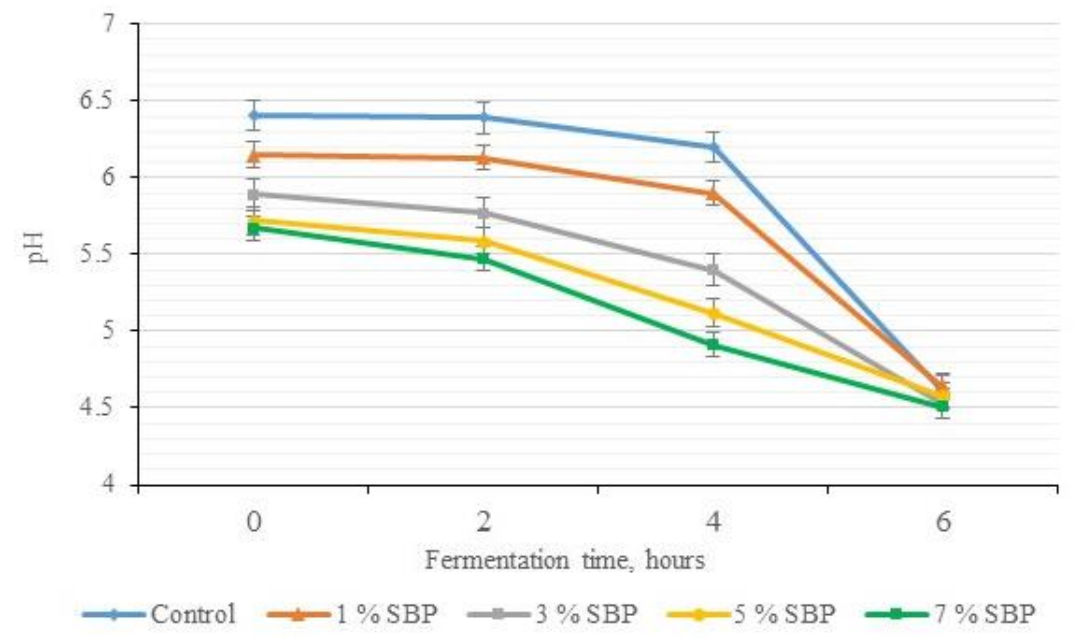

Figure 1. Evolution of yoghurt $\mathrm{pH}$ during the lactic fermentation process.

The results show that the initial $\mathrm{pH}$ values of yoghurt mixtures are also different. The difference is caused by the addition of sea buckthorn puree. The control sample registered the highest $\mathrm{pH}(6.41 \pm 0.1)$ and for the sample with $7 \%$ added sea buckthorn this value was the lowest $(5.67 \pm 0.08)$. The difference between the initial $\mathrm{pH}$ values is due to the organic acid-rich composition of sea buckthorn. Tiitinen et al. (2006) stated that malic, quinic, and ascorbic acids are predominant in the composition of sea buckthorn. During 6 hours of fermentation, the $\mathrm{pH}$ showed the same downward trend, up to the final values in the range of $4.51-4.64$. The reduction of the $\mathrm{pH}$ value of the analyzed samples is caused by the intensification of the lactic bacteria (Streptococcus thermophilus and Lactobacillus bulgaricus) activity, and respectively the transformation of sugars into lactic acid (Alonso et al., 2010).

\section{The evolution of $\mathrm{pH}$ and acidity during storage}

The most important buffering components of milk are caseins, phosphates, and citrates, although the quantitative allocation of the buffering capacity of these components is quite difficult to assess (Corredig et al., 2019). The interaction between them and other components of milk is accompanied by physicochemical 
changes such as $\mathrm{pH}$ and acidity, biochemical, and organoleptic changes. The $\mathrm{pH}$ variation for SBP yoghurt was determined over a period of 15 days.

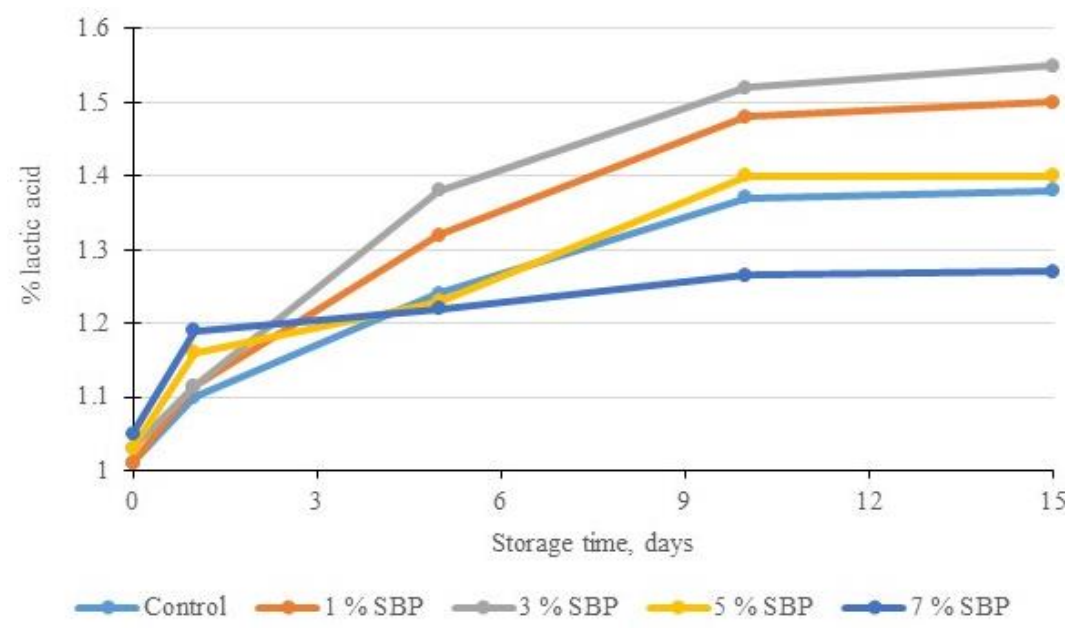

Figure 2. Evolution of sea buckthorn yoghurt acidity during storage time.

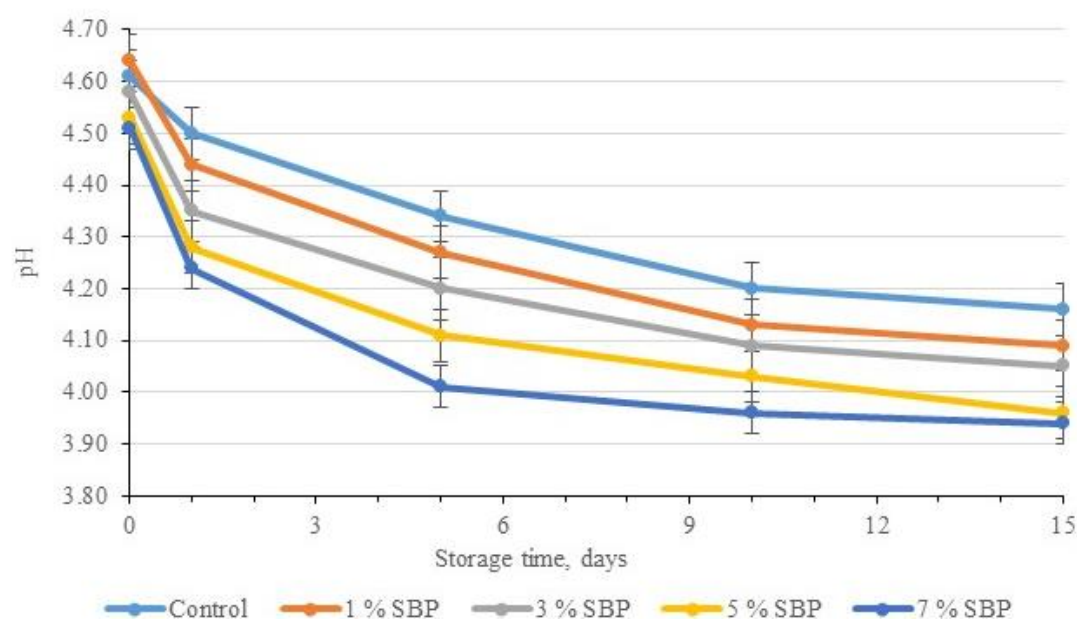

Figure 3. Evolution of sea buckthorn yoghurt $\mathrm{pH}$ during storage time.

According to the obtained results, a progressive increase of acidity was observed during the fermentation, for each of the investigated samples. A more pronounced increase in acidity is observed in the case of the sample with 3\% SBP which after 15 days of storage reaches the value of $1.55 \pm 0.06 \%$ lactic acid. For the $7 \%$ SBP yoghurt sample, the same increasing tendency of acidity is manifested, however with a lower tempou $(1.27 \pm 0.1)$, this difference is due to the high content of SBP which replaced the milk and which by its content inhibits the activity of lactic acid bacteria. Kontareva et al. (2020) reported titratable acidity values of $1.27 \%$ for yoghurt in the case of using blueberries as a source of prebiotics. On the other 
hand, for the yoghurt samples supplemented with strawberry, Şengül et al. (2014) reported titratable acidity values below $1 \%$.

The $\mathrm{pH}$ of samples with a higher SBP content is also influenced by the presence of organic acids in the SBP composition. Thus, for the sample with 7\% SBP, after 15 days of storage, the $\mathrm{pH}$ reached the value of 3.94, while for the control sample the value of 4.16 was registered.

\section{The evolution of yoghurt viscosity and syneresis during storage}

Yoghurt is a viscous-elastic fluid, the viscosity being the physical property, which reflects the size of the internal friction and is one of the most important properties that determine the consumption qualities, especially the stability of yoghurt. The evolution of the viscosity of yoghurt with SBP during 15 days of storage at $4{ }^{\circ} \mathrm{C}$ is presented in table 2.

Table 2. Evolution of yoghurt viscosity and syneresis during storage.

\begin{tabular}{lcccc}
\hline \multirow{2}{*}{ Sample } & \multicolumn{4}{c}{ Storage time, days } \\
\cline { 2 - 5 } & $\mathbf{5}$ & $\mathbf{1 0}$ & $\mathbf{1 5}$ \\
\cline { 2 - 5 } & \multicolumn{4}{c}{ Viscosity, cPs } \\
\hline Control & $5600.00 \pm 0.07^{\mathrm{a}}$ & $5998.56 \pm 0.05^{\mathrm{a}}$ & $6200.96 \pm 0.08^{\mathrm{a}}$ & $6050.45 \pm 0.11^{\mathrm{a}}$ \\
$\mathbf{1 \%}$ SBP & $5387.10 \pm 0.05^{\mathrm{b}}$ & $5820.00 \pm 0.06^{\mathrm{b}}$ & $6024.34 \pm 0.07^{\mathrm{b}}$ & $5821.56 \pm 0.07^{\mathrm{b}}$ \\
$\mathbf{3 \%}$ SBP & $5237.75 \pm 0.10^{\mathrm{c}}$ & $5602.64 \pm 0.04^{\mathrm{c}}$ & $5781.23 \pm 0.05^{\mathrm{c}}$ & $5624.45 \pm 0.02^{\mathrm{c}}$ \\
$\mathbf{5 \%}$ SBP & $4978.64 \pm 0.09^{\mathrm{d}}$ & $5398.45 \pm 0.05^{\mathrm{d}}$ & $5567.78 \pm 0.04^{\mathrm{d}}$ & $5298.20 \pm 0.04^{\mathrm{d}}$ \\
$\mathbf{7 \%}$ SBP & $4832.00 \pm 0.05^{\mathrm{e}}$ & $5254.35 \pm 0.01^{\mathrm{e}}$ & $5401.48 \pm 0.05^{\mathrm{e}}$ & $5100.00 \pm 0.11^{\mathrm{e}}$ \\
\hline \multicolumn{4}{c}{ Syneresis, \% $^{\mathrm{c}}$} \\
\hline Control & $28.97 \pm 0.04^{\mathrm{a}}$ & $25.81 \pm 0.03^{\mathrm{a}}$ & $24.22 \pm 0.02^{\mathrm{a}}$ & $32.23 \pm 0.05^{\mathrm{a}}$ \\
$\mathbf{1 \%}$ SBP & $29.76 \pm 0.03^{\mathrm{b}}$ & $28.22 \pm 0.02^{\mathrm{b}}$ & $26.27 \pm 0.06^{\mathrm{b}}$ & $34.12 \pm 0.03^{\mathrm{b}}$ \\
$\mathbf{3 \%}$ SBP & $31.16 \pm 0.03^{\mathrm{c}}$ & $29.33 \pm 0.04^{\mathrm{c}}$ & $27.86 \pm 0.05^{\mathrm{c}}$ & $34.87 \pm 0.03^{\mathrm{c}}$ \\
$\mathbf{5 \%}$ SBP & $31.42 \pm 0.04^{\mathrm{d}}$ & $29.45 \pm 0.05^{\mathrm{d}}$ & $28.39 \pm 0.04^{\mathrm{d}}$ & $35.17 \pm 0.04^{\mathrm{d}}$ \\
$\mathbf{7 \%}$ SBP & $33.23 \pm 0.04^{\mathrm{e}}$ & $30.65 \pm 0.04^{\mathrm{e}}$ & $29.14 \pm 0.02^{\mathrm{e}}$ & $37.24 \pm 0.02^{\mathrm{e}}$ \\
\hline
\end{tabular}

Insignificant differences ( $\mathrm{p}>0.05$ ), a-e: in each column different letters mean significant differences $(\mathrm{p}<0.001)$.

From the obtained results it can be concluded that the storage period influences the viscosity of the yoghurt by acidification and by the changes that the milk proteins undergo. Apparent viscosity is affected by the strength and number of bonds between the casein micelles in yoghurt, as well as their structure and spatial distribution (Al Sheraji et al., 2017). The apparent viscosity of SBP-enriched yoghurts is lower than that of the control sample. At the same time, for all yoghurt samples, there is an increase in viscosity during the first 10 days of storage, this may be due to the development of gel structure and changes in protein-protein bound in a three-dimensional protein matrix of yoghurt and their rearrangement (Shahbandari et al., 2016). After 10 days of storage the water holding capacity of yoghurt casein micelles decreases, this is because the addition of SBP can disrupt the gel structure of enriched samples. 
Serum release, known as syneresis, is considered one of the most important parameters that indicate the quality of yoghurt during storage. This effect occurs due to the sudden removal of hydrophilic macropeptides, which causes an imbalance of intermolecular forces. The bonds between the hydrophobic sites begin to develop and are applied by calcium bonds that form as the water molecules in the micelles begin to leave the structure (Unger Grundelius et al., 2000). The addition of SBP puree to yoghurt formulation significantly decreased viscosity and increased whey syneresis compared with the control sample and this increase was proportional to the SBP addition and to storage period (Table 2). Thus, during 15 days of storage, the syneresis index of the control sample registered a value of $32.23 \%$, while the samples with 7\% SBP registered values of over $37.24 \%$. Evaluating the obtained results, the optimal duration of yoghurt storing is established to be 10 days beforehand, after this period the accentuated process of syneresis does not allow to frame the product as a quality one.

These results are in agreement with those reported by Hallim et al. (2019) who stated that pomegranate or cactus juices addition decreased yoghurt viscosity and increased syneresis.

\section{The evolution of yoghurt optical density}

Bacterial growth curves were studied by determining the optical densities of the cells over a period of 60 hours at a wavelength of $600 \mathrm{~nm}$ using a spectrophotometer. (Stevenson et al., 2016). The different stages of bacterial growth (sigmoid form) were clearly observed (figure 4).

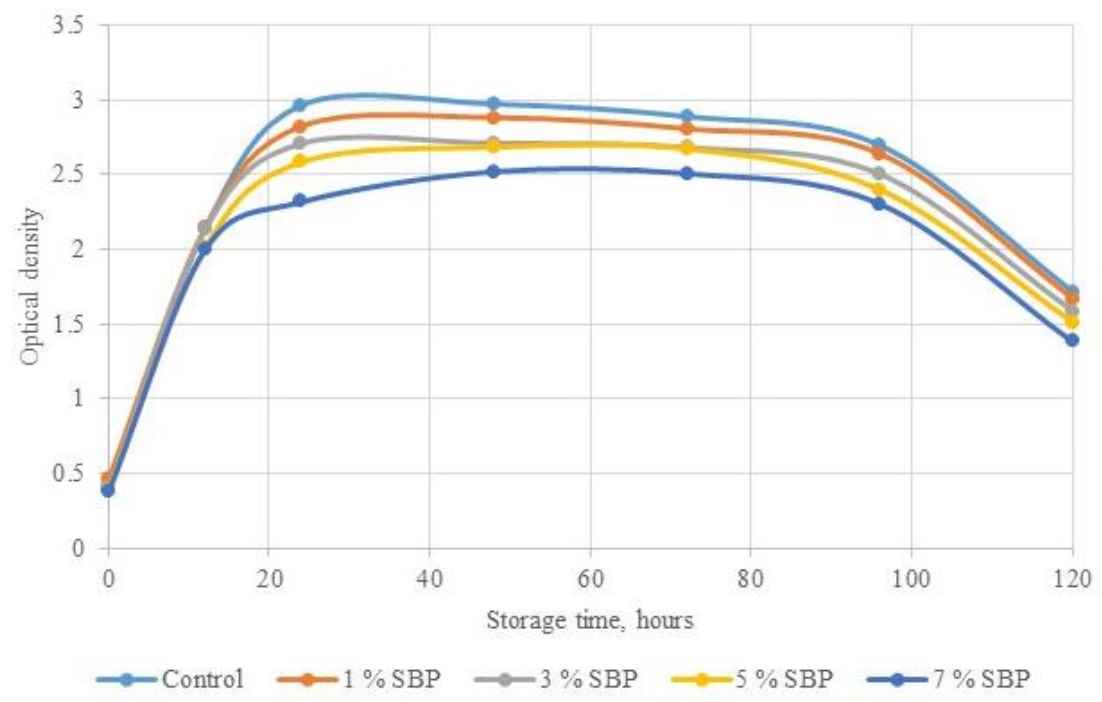

Figure 4. Evolution of sea buckthorn yoghurt optical density during storage time.

According to the graphical representation, there is a variation in the bacterial level of yoghurt samples from one stage to another caused by several factors. Thus, in 
the case of the five samples, it is observed practically the same kinetics of growth and then the decrease of the bacterial cells. For the control sample the initial value of the optical density is 0.421 , and for the sample with $1 \%$ sea buckthorn puree a higher density is registered, this being 0.467 - this could be explained by the presence of SBP and its loading with potential spontaneous ferments. In fact, the legitimacy between the ratio of SBP added and the number of lactic acid bacteria has been observed, it decreases with the increase of SBP addition. At the same time, all the curves that reflect this phenomenon have the same character, describing the phase of logarithmic development of the bacteria followed by the stationary phase and then decline. The stationary phase represented in the diagram is in an undulating state, but not in a constant state. This can be attributed to the fact that some cells easily synthesize some growth components than others. Jaishankar and Srivastava (2017) reported that growth in the stationary phase is unbalanced regardless of why the cells enter the stationary phase. As some components of the environment become more limited, the cells will continue to grow and divide for as long as possible. The optical densities of the cells decreased the metabolism and division of the cells as the cells entered the lethal phase. The same study showed that more viable cells are lost than those obtained in the lethal phase (Jaishankar and Srivastava, 2017). An optical density greater than 2,972 was recorded in the control sample in the stationary phase, then the bacteria showed an optical density of 1,717 indicating the decline / lethal phase. The stationary and lethal phases began at 24 and 96 hours respectively.

\section{Sensory analysis}

For sensory analysis, five basic parameters were assessed (color, taste, consistency, smell, and appearance). The overall liking of samples is presented in Table 3.

Table 2. Mean scores for color, appearance, flavor, taste, texture, and overall liking of studied yoghurt samples.

\begin{tabular}{|c|c|c|c|c|c|}
\hline \multirow{2}{*}{$\begin{array}{l}\text { Sensorial } \\
\text { attribute }\end{array}$} & \multicolumn{5}{|c|}{ Sample } \\
\hline & Control & $1 \%$ SBP & 3\% SBP & $5 \%$ SBP & $7 \%$ SBP \\
\hline Color & $5.00 \pm 0.00^{\mathrm{a}}$ & $5.00 \pm 0.00^{\mathrm{a}}$ & $4.81 \pm 0.07^{\mathrm{b}}$ & $4.81 \pm 0.07^{b}$ & $4.42 \pm 0.03^{\mathrm{c}}$ \\
\hline Appearance & $4.75 \pm 0.04^{\mathrm{a}}$ & $4.56 \pm 0.09^{b}$ & $4.64 \pm 0.04^{\mathrm{ab}}$ & $4.34 \pm 0.03^{c}$ & $4.06 \pm 0.04^{\mathrm{d}}$ \\
\hline Taste & $4.68 \pm 0.08^{\mathrm{bc}}$ & $4.57 \pm 0.06^{c}$ & $4.75 \pm 0.00^{\mathrm{ab}}$ & $4.87 \pm 0.08^{\mathrm{a}}$ & $4.84 \pm 0.07^{\mathrm{ab}}$ \\
\hline Flavor & $5.00 \pm 0.00^{\mathrm{a}}$ & $5.00 \pm 0.00^{\mathrm{a}}$ & $5.00 \pm 0.00^{\mathrm{a}}$ & $4.78 \pm 0.05^{\mathrm{b}}$ & $4.85 \pm 0.05^{\mathrm{b}}$ \\
\hline Texture & $4.88 \pm 0.0^{\mathrm{a}}$ & $4.72 \pm 0.07^{\mathrm{a}}$ & $4.83 \pm 0.06^{\mathrm{a}}$ & $3.95 \pm 0.03^{b}$ & $3.78 \pm 0.08^{c}$ \\
\hline $\begin{array}{c}\text { Overall } \\
\text { acceptability }\end{array}$ & $4.86 \pm 0.04^{\mathrm{a}}$ & $4.77 \pm 0.04^{\mathrm{a}}$ & $4.80 \pm 0.03^{\mathrm{a}}$ & $4.55 \pm 0.05^{\mathrm{b}}$ & $4.38 \pm 0.05^{c}$ \\
\hline
\end{tabular}

The highest scores for the texture were recorded for the $3 \%$ SBP sample. In terms of appearance, this sample also proves to be the most successful. Samples with 5\% and 7\% added SBP have a lower appreciation in this respect due to the 
inhomogeneous structure of sea buckthorn puree in yoghurt and due to the syneresis process, which proved to be much more accentuated with the increase of SBP content. On the other hand, samples with 5 and 7\% SBP in the matter of taste, received a high appreciation, specifying that they have a pleasant sour taste with accentuated shades of fruit. The intensity of the color is amplified with the increase of SBP content, but it is not uniform, thus proposing the preparation of this product as a drinkable yoghurt that would involve a pre-consumption stir. This process would also help to improve the consistency of the yoghurt, which in this case suffered from agglomerations of sea buckthorn puree. In general, all the tested yoghurt samples obtained scores above 3.0, on a five-point hedonic scale, and can be considered as acceptable.

\section{Conclusions}

The impact of sea buckthorn addition on the yoghurt physico-chemical indices, sensory quality, and nutritional value was analyzed. Regarding the physicochemical characteristics, non-essential deviations of viscosity and dry matter content caused by the addition of SBP were observed, which is explained by the fact that SBP has practically the same dry matter content as milk. The inversely proportional relationship between yoghurt acidity and their $\mathrm{pH}$ was established, data which are in accordance with the basic chemical principles.

After 15 days of storage, the sample with the highest acidity proved to be the sample with the addition of $3 \% \mathrm{SBP}$. The syneresis process is directly proportional to the evolution of acidity during storage, the sample with the most accentuated syneresis process being the sample with $7 \%$ sea buckthorn reaching a value of $37.24 \%$ syneresis.

The activity of the lactic acid bacteria has practically the same growth kinetics in the case of all samples during the first 48 hours of storage and is then followed by a decrease in the number of cells. There is no major influence of the addition of SBP in the bacterial cells development process. As a result of the sensorial examination, the samples with 5\% and 7\% SBP were assessed as the most successful in terms of taste intensity, but the process of manufacturing them is to be improved because the texture is not appropriate and the syneresis process is accentuated.

\section{Acknowledgments}

The research was funded by State Project 20.80009.5107.10, nr. PS-62 "Personalized nutrition and intelligent technologies for my well-being", running at Technical University of Moldova.

\section{References}

Adhikari, B., Bajracharya, G. 2018. Studies on qualities of probiotic yoghurt fortified with apple pulp and honey. Nepalese Journal of Agricultural Sciences, 16, 231. 
Al Sheraji, S.H., Alburihi, S., Nasser, Y.H., Mohammed Nagi, Y. 2017. Effects of Polysaccharides from Mango' Peel on Physiochemical and Sensory Properties of NonFat Yoghurts. Advances in Dairy Research, 05(03).

Alonso, S., Herrero, M., Rendueles, M., Díaz, M. 2010. Residual yoghurt whey for lactic acid production. Biomass and Bioenergy, 34(7), 931-938.

Bell, V., Ferrão, J., Fernandes, T. 2017. Nutritional Guidelines and Fermented Food Frameworks. Foods, 6(8), 65.

Chandan, R.C. (Ed.). 2006. Manufacturing yogurt and fermented milks (1st ed). Blackwell Pub.

Clark, S., Costello, M., Drake, M.A., Bodyfelt, F. (Eds.). 2009. The sensory evaluation of dairy products (2., ed). Springer.

Corredig, M., Nair, P. K., Li, Y., Eshpari, H., Zhao, Z. 2019. Invited review: Understanding the behavior of caseins in milk concentrates. Journal of Dairy Science, 102(6), 47724782.

da Silva, S.V. 2007. Desenvolvimento de iogurte probiótico com prebiótico. Thesis [Universidade Federal de Santa Maria].

Dreher, M. 2018. Whole Fruits and Fruit Fiber Emerging Health Effects. Nutrients, 10(12), 1833.

Ebringer, L., Ferenčík, M., Krajčovič, J. 2008. Beneficial health effects of milk and fermented dairy products-Review. Folia Microbiologica, 53(5), 378-394.

Fernandez, M.A., Marette, A. 2017. Potential Health Benefits of Combining Yogurt and Fruits Based on Their Probiotic and Prebiotic Properties. Advances in Nutrition: An International Review Journal, 8(1), 155S-164S.

Ghendov-Moşanu, A., Sturza, R., Opriş, O., Lung, I., Popescu, L., Popovici, V., Soran, M.L., Patraş, A. 2020. Effect of lipophilic sea buckthorn extract on cream cheese properties. Journal of Food Science and Technology, 57(2), 628-637.

Guo, X., Shi, L., Yang, S., Yang, R., Dai, X., Zhang, T., Liu, R., Chang, M., Jin, Q., Wang, X. 2019. Effect of sea-buckthorn pulp and flaxseed residues on quality and shelf life of bread. Food \& Function, 10(7), 4220-4230.

Hachana, Y., Rejeb, R., Chiboub, N., Zneidi, I.A. 2017. Variation factors of yoghurt quality during the manufacturing process. Journal of New Sciences, 41.

Hallim, A., Rabie, A., El-Shewey, M., Abdel-Ghany, A. 2019. Evaluation of physicochemical properties and antioxidant activity of stirred yoghurt fortified with pomegranate and cactus pear juices. Zagazig Journal of Agricultural Research, 46(6), 1995-2008.

Jaishankar, J., Srivastava, P. 2017. Molecular Basis of Stationary Phase Survival and Applications. Frontiers in Microbiology, 8, 2000.

Jeantet, R., Croguennec, T., Mahaut, M., Schuck, P., Brule, G. 2008. Les produits laitiers. Éd. Tec \& doc.

Johnston, C., DeVries, T.J. 2018. Short communication: Associations of feeding behavior and milk production in dairy cows. Journal of Dairy Science, 101(4), 3367-3373.

Kleyn, D.H., Lynch, J.M., Barbano, D.M., Bloom, M.J., Mitchell, M.W., Collaborators:, Cooper, L.S., Cusak, E., Fick, M., Hanks, T., Hesen, M.K., Johnson, J., Kleyn, D.H., Mercer, F., Monahan, D., Peat, B., Petit, M. 2001. Determination of Fat in Raw and Processed Milks by the Gerber Method: Collaborative Study. Journal of AOAC International, 84(5), 1499-1508.

Kontareva, V.Y., Belik, S.N., Morgul, E.V., Gorlov, I. F., Slozenkina, M.I. 2020. The effect of prebiotic components on the quality of yogurt. IOP Conference Series: Earth and Environmental Science, 548, 082054. 
Kuhkheil, A., Naghdi Badi, H., Mehrafarin, A., Abdossi, V. 2017. Chemical constituents of sea buckthorn (Hippophae rhamnoides L.) fruit in populations of central Alborz Mountains in Iran. Research Journal of Pharmacognosy, 4(3), 1-12.

Laird, E., Molloy, A.M., McNulty, H., Ward, M., McCarroll, K., Hoey, L., Hughes, C.F., Cunningham, C., Strain, J.J., Casey, M.C. 2017. Greater yogurt consumption is associated with increased bone mineral density and physical function in older adults. Osteoporosis International, 28(8), 2409-2419.

Li, E., Mira de Orduña, R. 2010. A rapid method for the determination of microbial biomass by dry weight using a moisture analyser with an infrared heating source and an analytical balance. Letters in Applied Microbiology, 50(3), 283-288.

Mediza Romero, M.L., von Staszewski, M., Martínez, M.J. 2021. The effect of green tea polyphenols addition on the physicochemical, microbiological and bioactive characteristics of yogurt. British Food Journal, 123(7), 2380-2397.

Najgebauer-Lejko, D., Liszka, K., Tabaszewska, M., Domagała, J. 2021. Probiotic Yoghurts with Sea Buckthorn, Elderberry, and Sloe Fruit Purees. Molecules, 26(8), 2345.

Pyne, G.T. 1932. The determination of milk-proteins by formaldehyde titration. Biochemical Journal, 26(4), 1006-1014.

Roman, D., Constantin, O.E., Stănciuc, N., Râpeanu, G. 2020. Bioactive Compounds and Antioxidant Activity in Different Extracts of Sea Buckthorn. The Annals of the University Dunarea de Jos of Galati Fascicle VI - Food Technology, 44(1), 178-192.

Sadler, G.D., Murphy, P.A. 2010. PH and Titratable Acidity. In S. S. Nielsen (Ed.), Food Analysis (pp. 219-238). Springer US.

Şengül, M., Erkaya, T., Yildiz, H. 2014. An investigation of the antioxidant activities and some physicochemical characteristics of strawberry added yogurt. Italian Journal of Food Science, 26(3), 235-242.

Shahbandari, J., Golkar, A., Taghavi, S. M., Amiri, A. 2016. Effect of Storage Period on Physicochemical, Textural, Microbial and Sensory Characteristics of Stirred Soy Yogurt. International Journal of Farming and Allied Sciences (Pakistan). 5(6):476484.

Shi, L., Zheng, L., Zhao, C., Jin, Q., Wang, X. 2019. Chemical composition and antioxidant capacity of extracts from the whole berry, pulp and seed of Hippophae" rhamnoides ssp. Yunnanensis. Natural Product Research, 33(24), 3596-3600.

Sidor, A.-M., Gutt, G., Dabija, A., Sanduleac, E.T., Sidor, V. 2017. The effect of yogurt enrichment with sea buckthorn powder on its sensory acceptance, rheological, tehtural and physicochemical properties. Proceedings of 17th International Multidisciplinary Scientific GeoConference SGEM 2017, 61, 1117-1128.

Soliman, T.N., Shehata, S.H. 2019. Characteristics of fermented camel\&rsquo;s milk fortified with kiwi or avocado fruits. Acta Scientiarum Polonorum Technologia Alimentaria, 18(1), 53-63.

Stevenson, K., McVey, A.F., Clark, I.B.N., Swain, P.S., Pilizota, T. 2016. General calibration of microbial growth in microplate readers. Scientific Reports, 6(1), 38828.

Tiitinen, K.M., Yang, B., Haraldsson, G.G., Jonsdottir, S., Kallio, H.P. 2006. Fast Analysis of Sugars, Fruit Acids, and Vitamin C in Sea Buckthorn (Hippophaë rhamnoides L.) Varieties. Journal of Agricultural and Food Chemistry, 54(7), 2508-2513.

Torres, E.A.F.S., Campos, N.C., Duarte, M., Garbelotti, M.L., Philippi, S.T., MinazziRodrigues, R.S. 2000. Composição centesimal e valor calórico de alimentos de origem animal. Ciência e Tecnologia de Alimentos, 20(2), 145-150. 
Unger Grundelius, A., Lodaite, K., Östergren, K., Paulsson, M., Dejmek, P. 2000. Syneresis of submerged single curd grains and curd rheology. International Dairy Journal, 10(7), 489-496.

Ursache, F.M., Andronoiu, D.G., Ghinea, I.O., Barbu, V., Ioniţă, E., Cotârleţ, M., Dumitraşcu, L., Botez, E., Râpeanu, G., Stănciuc, N. 2018. Valorizations of carotenoids from sea buckthorn extract by microencapsulation and formulation of value-added food products. Journal of Food Engineering, 219, 16-24.

Vénica, C.I., Spotti, M.J., Pavón, Y.L., Molli, J.S., Perotti, M.C. 2020. Influence of carrot fibre powder addition on rheological, microstructure and sensory characteristics of stirred-type yogurt. International Journal of Food Science \& Technology, 55(5), 19161923.

Verbeyst, L., Bogaerts, R., Van der Plancken, I., Hendrickx, M., Van Loey, A. 2013. Modelling of Vitamin C Degradation during Thermal and High-Pressure Treatments of Red Fruit. Food and Bioprocess Technology, 6(4), 1015-1023.

Visioli, F., Strata, A. 2014. Milk, Dairy Products, and Their Functional Effects in Humans: A Narrative Review of Recent Evidence. Advances in Nutrition, 5(2), 131-143.

Yanni, A.E., Kartsioti, K., Karathanos, V.T. 2020. The role of yoghurt consumption in the management of type II diabetes. Food \& Function, 11(12), 10306-10316.

Yanni, A.E., Kokkinos, A., Psychogiou, G., Binou, P., Kartsioti, K., Chatzigeorgiou, A., Konstantopoulos, P., Perrea, D., Tentolouris, N., Karathanos, V.T. 2019. Daily consumption of fruit-flavored yoghurt enriched with vitamins B contributes to lower energy intake and body weight reduction, in type 2 diabetic patients: A randomized clinical trial. Food \& Function, 10(11), 7435-7443.

Zheng, H., Mao, L., Yang, J., Zhang, C., Miao, S., Gao, Y. 2020. Effect of Oil Content and Emulsifier Type on the Properties and Antioxidant Activity of Sea Buckthorn Oil-inWater Emulsions. Journal of Food Quality, 2020, 1540925.

Zielińska, A., Nowak, I. 2017. Abundance of active ingredients in sea-buckthorn oil. Lipids in Health and Disease, 16(1), 95. 